\title{
Language and the Circuits of Power in a Merging Multinational Corporation
}

\author{
Eero Vaara \\ Swedish School of Economics and Business Administration, Finland, \\ Ecole de Management de Lyon, France \\ Janne Tienari \\ Lappeenranta University of Technology, Finland \\ Rebecca Piekkari \\ Helsinki School of Economics, Finland \\ Risto Säntti \\ Nordea, Finland
}




\begin{abstract}
We argue in this paper that corporate language policies have significant power implications that are easily overlooked. By drawing on previous work on power in organizations (Clegg, 1989), we examine the complex power implications of language policy decisions by looking at three levels of analysis: episodic social interaction, identity/subjectivity construction, and reconstruction of structures of domination. In our empirical analysis, we focus on the power implications of the choice of Swedish as the corporate language in the case of the recent banking sector merger between the Finnish Merita and the Swedish Nordbanken. Our findings show how language skills become empowering or disempowering resources in organizational communication, how these skills are associated with professional competence, and how this leads to the creation of new social networks. The case also illustrates how language skills are an essential element in the construction of international confrontation, lead to a construction of superiority and inferiority, and also reproduce post-colonial identities in the merging bank. Finally, we also point out how such policies ultimately lead to the reification of post-colonial and neo-colonial structures of domination in multinational corporations.
\end{abstract}

\title{
INTRODUCTION
}

Natural languages have received very little attention in organization and management studies. This is unfortunate since natural languages are the basic means of communication in organizations, the basis for knowledge creation, and signifiers and symbols of ethnic and national culture/identity. Most of the organization and management literature that does exist tends to view language questions as communication challenges to be solved by carefully designed policies and training programmes. We, however, argue in this paper that this is only one part of the story.

In this paper, we focus on the language policy choices made in merging multinational corporations. We in particular argue that corporate language policies should not merely be treated as practical means to solve inevitable communication problems; rather, they should be viewed as exercise of power. Mapping out these power implications, however, requires a theoretical framework. In this paper, we develop such a framework by drawing on previous work on power in organizations. In particular, we make use of the 'circuits of power' idea of 
Stewart Clegg (1989). Accordingly, we examine the complex power implications of language policies at three intertwined levels of analysis: episodic social interaction, identity/subjectivity construction, and reconstruction of structures of domination.

To examine and elaborate on the power implications of corporate language policies, we examine a Nordic merger between the Finnish Merita Bank and the Swedish Nordbanken. This merger can be seen as a pioneering case in the European banking sector because it brought together for the first time leading retail banks operating in different countries. Our analysis focuses on the controversial decision to choose Swedish as the 'official corporate language' and its power implications. By drawing on rich ethnographic material gathered, we illustrate and specify the circuits of power in language policy questions. Our findings show how language skills become empowering or disempowering resources in organizational communication, how these skills are associated with professional competence, and how this leads to the creation of new social networks. The case also illustrates how language skills are an essential element in the construction of international confrontation, can lead to a construction of superiority and inferiority, and also reproduce post-colonial identities in the merging bank. Finally, we also point out how such policies ultimately lead to the reification of post-colonial and neo-colonial structures of domination in multinational corporations.

\section{THE ROLE OF NATURAL LANGUAGES IN MERGING MULTINATIONAL CORPORATIONS}

The role of natural languages in social life can hardly be overestimated. In brief, one can link language with culture, knowledge and power. For most people, 'language' has always represented the core of culture, although what is taken as 'culture' has been debated throughout history. Natural languages in particular represent the heart and symbol of specific national and ethnic cultures, although the relationship between specific languages and nation states is not at all straightforward (e.g. Anderson, 1983).

One can see the 'linguistic' turn in social sciences as evidence of the increasing recognition of the importance of language in the social construction of reality (Berger and Luckmann, 1966; Garfinkel, 1967; Wittgenstein, 1968). Although people may hold fundamentally different views as to what is the specific role of language or discourse in this construction, most agree that natural languages (like other discourses) provide specific 
frameworks through which ideas and issues are translated and constructed. This also provides the link to knowledge. In brief, it is the linguistic (re)presentation that most see as essential in the social constitution of knowledge (Berger and Luckmann, 1966; Wittgenstein, 1968).

What is important for our present analysis is that language and knowledge are also linked with power (e.g. Clegg, 1989). The traditional view emphasizes that specific discourse and practices empower particular parties and disempower others. From a more radical perspective, languages and discourses can also have power over people in ways that are not obvious in everyday social interaction. One can also take a post-modern view and see language, knowledge and power as intertwining elements in the social construction of identities and subjectivities (e.g. Foucault, 1980).

Organizational scholars have examined language use in organizational processes and practices and highlighted the culture-knowledge-power linkages from the early 1970s. For example, language has been shown to be a central element in organizational selection processes, in the consequent constitution of organizational relationships and their power implications (e.g. Silverman and Jones, 1974). Language has also been explicitly linked with organizational rationalities, rules and domination (Clegg, 1975, 1987). Although these early analyses are still exceptions in terms of their explicit analytical treatment of the constitutive role of language in organizational life, it is fair to say that the central role of language in organizations is now widely established by various kinds of discourse analysis (e.g. Grant et al., 1998; Hamilton, 2003; Westwood and Linstead, 2001).

Natural languages have, however, received very little explicit attention by organizational scholars. This is unfortunate as such, but especially problematic when trying to understand the increasingly important role of multinational corporations in the contemporary global order (Alvesson and Willmott, 1996; Banerjee and Linstead, 2001; Child and Tsai, 2005; Deetz, 1992a; Korten, 1996). The MNC has, in fact, emerged as the dominant organizational form for large international businesses and even other international organizations. Especially interesting in these organizations are the in-built tensions created by multiple cultures, nationalities and languages. It would, however, be a mistake to think about these organizations as stable structures detached from their environment. Increasingly, corporations have been growing and creating ever-larger corporate empires by mergers, acquisitions, alliances and other structural arrangements. Especially cross-border mergers and 
acquisitions have become more and more popular and can nowadays be seen as a major mechanism through which new MNCs are being constructed.

A cross-border merger involving the juxtaposition and confrontation of two parties having two different mother tongues is arguably a setting that enables us to have a close look at the power implications of specific languages. Language issues and problems are likely to be evident especially when negotiating and specifying particular communication and decision-making practices and when confronting the 'Other' in the reality of the post-merger organization. On the one hand, from the corporate perspective, the different natural languages are likely to pose a need to agree upon and control communication and decision-making practices so that the language differences do not hamper 'effective' functioning of the new post-merger corporation. On the other, the situation is likely to be characterized by national cultural confrontation where the two natural languages are concrete examples, signifiers and emblems of national identification. The analysis of the power implications, however, requires a conceptual framework that enables us to specify the various types of effects and process at work.

\section{TOWARDS AN UNDERSTANDING OF THE CIRCUITS OF POWER IN LANGUAGE POLICIES}

In social studies, 'power' has been conceptualized in many different ways, which can be seen both as a reflection of the importance of 'power relationships' in social analyses and as a sign of the multidimensional nature of 'societal, 'social' or 'organizational' power. In brief, roots of different traditions can be traced as far as Hobbes and Macchiavelli (e.g. Clegg, 1989). Classical writers like Marx and Weber have also paid specific attention to 'power'; Marx linking power with class structures and confrontation in society, Weber holding a pluralistic or more complex view. Gramsci (1971), in turn, has created a widely used approach where 'hegemony' is seen as the overarching cultural and linguistic power characterizing specific social settings. Thereafter, especially the political and sociological analyses of the 1960s and 1970s have advanced these conceptualizations. For example, Bachrach and Baratz (1963)

paid specific attention to 'non decision-making' as (at least) equally important to 'decisionmaking analyses' when understanding power in societies and organizations. Lukes (1974) later presented a model of three dimensions that advanced power analyses so that in addition 
to concrete decisionmaking (first dimension) and non-decision-making (second dimension), the institutionalized power that is exercised to socially construct reality also became highlighted (third dimension). This means that those who are able to control meaning are thus in a position to render the others powerless, but also that people are not usually aware of this construction of reality.[1] This led to a general acceptance of the idea that 'power' is not only something possessed by specific actors but also embedded in the social structures, traditions, and conventions.

Of the contemporary sociologists, for example, Giddens (1984) has advocated a 'classical' view according to which 'power' is the (causal) ability of agents (working within a framework of specific structures) to mobilize specific rules and resources. An alternative 'post-modernist or post-structuralist' conception has grown out of Foucault's $(1977,1984)$ work on discourses and practices where social actors are perhaps more controlled and disciplined by 'faceless' social practices and discourses rather than vice versa. These discourses and practices, according to the post-structuralist perspective, actually construct subject positions and identities for social actors. In the Foucauldian 'micro-politics', power relationships are complex in the sense that also those conventionally seen as 'powerless' have and exercise particular power over those conventionally seen as the 'dominators' and that acts of resistance - conventionally seen as a counter-force to power - are an inherent part of the construction of power relations. Other post-structuralists have developed similar ideas. For example, Laclau and Mouffe (1985) have focused on the semiotic side of power, arguing that 'power' is above all textual in that it lies in the meaning and signification of social activity. Such views have also been criticized for an overly deterministic view on power where the role given to individual subjects and selves is limited. At the extreme individuals are seen as 'puppets' moved around by invisible or faceless discourses. Others have also pointed to a fact that by questioning the very existence of 'stable' structures, poststructuralists have provided a relativist scenario where the possibility of critique of apparent structural inequalities and subordination is rather limited.

Particularly relevant for our analysis, 'post-colonial' researchers have examined the relationship between colonizing and colonized cultures and people from a power/domination perspective. Especially the work of Saïd (1979) has been influential and inspiring in illustrating how the cultural and socio-political hegemony of the West has subordinated the peoples of the Third World (e.g. Kennedy, 2000). This has indeed provided keys to 
understand how particular relationships between specific people, ethnic groups and nations are overshadowed by (often problematic) historical heritages. This is most visible in the cases where the cultural and socio-political influences of the colonizer determine the development of the colonized societies. Although the theoretical underpinnings of the post-colonial perspective are debated, this approach has lately inspired many postmodernist researchers outside the immediate colonial debates to try to understand the social forces behind marginalization and exclusion (e.g. Kennedy, 2000). Interestingly, the idea of "neocolonization' has lately come to signify specifically Western-driven globalization hegemony.

Many scholars, including the post-structuralistically oriented post-colonialist scholars, have also started to pay increasing attention to 'resistance strategies' as an essential part of power relationships. While even the more classical conceptions of power have emphasized the fact that power is most visible in the behaviour and actions of the 'powerless', more recent analyses have brought to the fore the idea that resistance can also be seen as a continuous process of adaptation and reinscription of the dominant discourses as well as inventive in terms of creating new types of practice and discourse level responses to challenging social situations.

Organizational analyses have also made use of different power theories, for example, in the context of decision-making (e.g. Miller et al., 1996). Traditional organizational analyses have often distinguished 'legitimate power' deriving from the hierarchical positions of those who exercise power over their subordinates and 'illegitimate power' in social networks and actor relationships (Mintzberg, 1983; Pettigrew, 1973; Pfeffer, 1992; Thompson, 1956), closely connected to the ideas of 'non decision-making' put forward by Bachrach and Baratz. In fact, some have argued that it is precisely these informal relationships that are the most interesting and important power mechanisms in organizations (Mintzberg, 1983).

It is fair to say that most organizational analysis of power have more or less shared the resource-based view. However, a number of studies have also been inspired by different types of post-structuralist or post-modernist views and paid specific attention to discourses and discursive mechanisms (re)creating and (re)producing power relationships in and around organizations (e.g. Ball and Wilson, 2000; Brocklehurst, 2001; Carter and Jackson, 2004; Deetz, 1992b; Ezzamel et al., 2001; Gowler and Legge, 1981; Knights and McCabe, 1999; Knights and Willmott, 1989; Townley, 1993). These studies have most often been 'critical' in 
tone and examined the (re)construction and (re)production of power relationships and inequalities in the context of management and organizing (e.g. Alvesson and Willmott, 1996; McKinlay and Starkey, 1998). Foucauldian perspectives have in particular been found useful in studies of disciplinary practices (e.g. Townley, 1993, 2004) as well as in analyses of subjugation and subjectivication (e.g. McKinley and Starkey, 1998). What is specifically important for our present study is that also post-colonial perspectives have gained popularity in various kinds of analysis (see e.g. Prasad, 1997, 2003) as have criticisms of neocolonialism (e.g. Banerjee and Linstead, 2001).

Several authors have also synthesized these different conceptions and views in organization studies (e.g. Alvesson and Willmott, 1996; Clegg, 1989). A notable effort is that by Clegg (1989) where he put forward a framework of 'circuits of power'. Within this framework, he brings together (1) episodic power relationships manifested in concrete situations where different social agents interact, (2) rules of practice that fix relations of meaning and membership (that both define identities and subjectivities for the actors/agents interacting in specific episodes and are affected by these interactions), and (3) related structures of domination constituted by the social practices and techniques empowering or disempowering the actors/agents (see Clegg, 1989, p. 214 for a graphical presentation of the model). The point with the term 'circuit' is that it means that all three levels of analysis are connected to each other.

In this paper, we draw from the ideas of Clegg and adopt an integrative view on power in organizations. Following Clegg, we want to link 'observable' episodic social interactions with 'deeper' level meaning creation and membership definition processes (constructing identities and subjectivities) and further see how a fixing of the social relationships and related practices and techniques creates more permanent structures in social life in general and organizations in particular. According to this view, we can thus analytically link 'observable' events of 'power' or 'powerlessness' with 'naturalized' social and organizational practices, techniques and structures of domination constituted by them. While Clegg's analysis is theoretical and encompasses various kinds of elements, we will, however, in the following mainly concentrate on the language policies of multinational corporations and their effects on national identity/subjectivity construction processes in organizational settings as outlined below. 
In brief, when examining the power implications of language policies we can look at (1) episodic interactions between particular actors, some of them possessing and other not possessing particular resources (mainly language skills) specific to the interaction type and this resulting in particular outcomes, (2) identity and subjectivity construction involving (re)construction power relationships between these actors, and (3) reification of structures of domination when normalizing specific identities and subjectivities and particular practices and techniques. This analytical framework is summarized in Table I.

Table I. The framework: the power implications of corporate language policies

\begin{tabular}{|c|c|c|}
\hline & Concept of power & Power implications \\
\hline $\begin{array}{l}\text { Language and social } \\
\text { interaction }\end{array}$ & $\begin{array}{l}\text { (Episodic) Power in social } \\
\text { interaction }\end{array}$ & $\begin{array}{l}\text { Language skills as empowering or } \\
\text { disempowering resources in everyday } \\
\text { communication } \\
\text { Language skills as part of professional } \\
\text { competence } \\
\text { Emerging networks of communication }\end{array}$ \\
\hline $\begin{array}{l}\text { Language and the } \\
\text { construction of } \\
\text { identity/subjectivity }\end{array}$ & $\begin{array}{l}\text { Power as part of identity/ } \\
\text { subjectivity construction }\end{array}$ & $\begin{array}{l}\text { Reconstruction of inter-national } \\
\text { categories and confrontation } \\
\text { Construction of superiority and } \\
\text { inferiority relationships (e.g. post- } \\
\text { colonial identities) }\end{array}$ \\
\hline $\begin{array}{l}\text { Language and the } \\
\text { reification of structures } \\
\text { of domination }\end{array}$ & $\begin{array}{l}\text { Power as hierarchical } \\
\text { structures of } \\
\text { domination }\end{array}$ & $\begin{array}{l}\text { Recreation of post-colonial cultural } \\
\text { and political hegemonies } \\
\text { Neo-colonial structuration of } \\
\text { multinational corporations }\end{array}$ \\
\hline
\end{tabular}

At the level of observable social interaction, language skills facilitate understanding and communication and thereby have many kinds of power implications in organizational life. These skills can in many professions also turn out to be significant determinants of professional competence. They can also contribute to the creation of language-based networks for accessing information and knowledge. Managers and other people with the right language skills may easily occupy gatekeeping positions and channel information between merging organizations. In this way, their power may increase far beyond the formal position in everyday organizational life (Marschan-Piekkari et al., 1999). 
At the second level, the selected language also (re)constructs and defines meanings and membership categories in the merging multinational corporation, implying complex identity and subjectivity construction. This identity and subjectivity construction is likely to be an ongoing process which often passes unnoticed on the surface of everyday life in multinational corporations. The constructed identities of specific actors may also be ambiguous, fragmented and even contradictory. Nevertheless, in such settings, national identities symbolized by language easily become specifically salient and significant social categories and identities. In fact, one can assume that a selection of a particular language will inadvertently create superiority-inferiority relationships between the people belonging or not belonging to the group that shares the language and the culture symbolized by it. This is likely to be reflected in whether particular people are then considered to be 'winners' or 'losers', representatives of the dominating or dominated party, more or less competent, or possible candidates for top positions. Those falling within the 'loser' camp are obviously likely to suffer in the long-term from this kind of setting in terms of their ability to be included in the central circles of decision- making or progress in their career ladder. However, neither is the identity of those attached a 'privileged' label uncomplicated as their actions may often be considered - especially by the dominated party - precisely within that framework. One can also link specific choices with the historical relationships between particular nations or people and uncover, for example, post-colonial relationships being (re)created by specific language practices. In brief, selecting and enforcing the use of the language of the colonizer is undoubtedly likely to (re)produce at least some traces of the colonial relationship.

At the third level, the institutionalization and normalization of specific identities and practices and related practices and techniques leads to the reification of structures of domination, that is, fixed social power relationships in the specific setting. What adds to the importance of these structures - and the specific practices and techniques constituting them is that people are not usually fully aware of them or at least take them for granted in social interaction. In any case, the fixation of specific languages policies in MNCs tends to create organizational hierarchies along the colonizer-colonized axis. One can here also think that the formulation and implementation of specific language policies (re)create specific hierarchical control mechanisms in multinational corporate organizations, promoting the position of the corporate management as an agency the power of which should also concern communication and self-expression within the corporate setting. Such actions - albeit often 
'necessary' from the point of view of the corporation - also mean that the corporate power is extended to spheres of life that have in many ways been thought to be independent of one's working careers such as expression and communication.

\section{THE ETHNOGRAPHIC CASE STUDY}

In our empirical analysis, we concentrate on the power implications of the choice of Swedish as the corporate language in the case of the recent banking sector merger between the Finnish Merita and the Swedish Nordbanken. Our analysis focuses on the power implications on the Finnish side of the post-merger organization, which had to adapt to, cope with and develop means to resist the use of Swedish as the 'official corporate language'. However, we base our analysis on information gathered on both Finnish and Swedish sides.

Our case study draws on rich ethnographic material (e.g. Van Maanen, 1988) from three sources: (1) participant observation, (2) thematic interviews with current and former employees of MeritaNordbanken, and (3) analysis of media texts. First, one of the authors of this article works for the Finnish Merita and the new Finnish-Swedish MeritaNordbanken organization (MNB). As a manager in personnel development, he has had a unique opportunity to observe how Finns and Swedes reacted to the merger. More specifically, he was intimately involved in developing a language training policy for the Finnish organization within MNB. This work produced material concerning a wide range of language problems. He was also the leader and facilitator of cultural seminars for some 350 Finnish and Swedish managers and experts involved in cross-national communication. In these seminars, taking place from October 1998 to January 2000, the choice and use of Swedish as the common corporate language, the necessary level of fluency to be attained among the personnel, and the need to change this corporate language into English were thoroughly debated. Since these seminars were held in Swedish, they clearly revealed problems among the Finnish participants, such as inability to express oneself fluently and fatigue caused by efforts to operate in a foreign language. Moreover, another author of the paper has been involved in executive training of MNB and consulting the organization. These observational data form the core of the research material.

Second, our empirical material comprises in-depth thematic interviews of Finns and Swedes. Nine semi-structured, in-depth interviews with individuals in several units of 
MeritaNordbanken were conducted from January to March 2000. These interviewees represented different hierarchical and professional positions on the Finnish side of the bank. The interviews were thematically structured. The interview themes were the following: views on the corporate culture, the role and choice of the official corporate language, corporate culture development seminars and activities. However, within this thematic framework the idea was to try to let the interviewee express his/her experiences as authentically as possible. All these interviews were recorded and transcribed verbatim. In practice, a preliminary thematic analysis of this material provided us with rich overall understanding of how people on the Finnish side experienced and interpreted the language policy issue.

A second round of interviews was conducted as part of larger research project focusing on the cultural and socio-political aspects of integration in the Merita- Nordbanken merger (October 1997), in the subsequent merger between MeritaNordbanken and the Danish Unidanmark (March 2000), and the acquisition of the Norwegian Christiania Bank and Kreditkassen by this group (October 2000).[2] This provided us with a possibility to follow up the developments in this case, to specifically focus on the top-decision makers' experiences and interpretations on both Finnish and Swedish sides and to place this language issue in a broader socio-political context. A total of 53 interviews targeting the top decisionmakers in these banking organizations were conducted in the latter part of 2001 and the beginning of 2002. The idea was to employ a 'story telling approach' with the use of a semistructured interview guide. To ensure that the interviews focused on particular themes, specific questions related to, for example, cultural differences and inter-national interaction were included in the agenda. There were two explicit questions focusing on the language policies and practices of the group. All the interviews were recorded and transcribed verbatim. For the purposes of the present article, we focused on the 13 Finnish and 11 Swedish top managers, covering in practice the key top managerial decision-makers on both sides. In both cases, one manager was interviewed twice, meaning that the total number of interviews was $14+12$ for this second round. In the case of this material, apart from crude thematic analysis complementing that of the previous interviews, we could also make interesting discursive observations concerning how the interviewees saw the initial decision and its implications. To put it bluntly, this was a very important question for most Finns who often gave it a specifically important role in their narratives while it was less important for Swedes. We could also clearly see how those who were generally seen as responsible for the initial 
decision tended to defend the choice as well as downplay its consequences while almost all others were eager to point to the problematic consequences.

Third, our empirical material includes articles published in leading Finnish printed media on the MeritaNordbanken merger. This material covers the merger during its first full year (October 1997 - October 1998), with an emphasis on the two-week period following the announcement of the merger. The analysis comprised the coverage in the following media:

- Helsingin Sanomat (the leading daily newspaper)

- Ilta-Sanomat (the leading tabloid)

- Kauppalehti (the leading daily business newspaper)

- Talouselämä (the leading weekly business magazine)

By drawing on earlier work in this area using critical discourse analysis (Fairclough, 1997; Harley and Hardy, 2004; Vaara and Tienari, 2002), we concentrated on those news and texts that touched upon the language issue. In this analysis, we first looked for dominant themes, then examined the various types of discourse involved, and finally analysed the linkages between the discursive framings (ways of constructing the language issue) and the sociocultural practices in the banking organization (as we understood them based on our observational and interview data).

These three sources provided us with a very rich empirical database on the language policy issue. What we did in practice was to first work on an 'empirical reconstruction' of the actual events and related sensemaking processes on the Finnish side of the organization by working and re-working on the key themes emerging from the participant observation, interview and media material.We then took Clegg's (1989) work - because it represented a rare synthesis of different conceptions of power - as a preliminary frame of reference and used that to interpret the power implications of the language policy question in this case. This led us to refine our theoretical frame, as outlined in the previous section, and to identify specifically interesting illustrations as well as 'holes' in our empirical analysis. By going back to the empirical material, we could then supplement and refine our analysis to the extent that we could back up our empirical arguments with credible examples. At the same time, we 
could also develop our theoretical understanding so that we could summarize our findings as indicated in the figure in the concluding section.

This kind of interpretive analysis is by its very nature 'subjective' and therefore characterized by various 'biases'. In our case, it is most important to note that we have been actively involved in reconstructing the empirical material as participant observers and interviewers. Our material is thus prone to, for example, emphasize the importance of the language policy issue. However, we have tried to balance this by interview techniques enabling the interviewees to describe their experiences as authentically as possible and by making use of the extensive media coverage around the case. It should also be noted that all of us authors are Finnish. This undoubtedly creates a certain kind of 'bias' in our interpretations. Including Swedish interviews in this analysis and discussing our analysis informally with people representing other nationalities in the case organization has arguably helped to balance our interpretations and conclusions. Furthermore, it should be emphasized that we are not in this article trying to create an 'objective' overview of language policy issue in MeritaNordbanken but rather aiming at uncovering and illustrating the complex power implications of corporate language policies from a theoretically grounded perspective.

\section{THE CHOICE OF THE CORPORATE LANGUAGE IN MERITANORDBANKEN}

Sweden and Finland are neighbouring countries in northern Europe and they share a common social history. From 1323 until 1809, Finland was part of the Kingdom of Sweden. Finland adopted its judicial system, governmental administration and basic political structure from its Western neighbour. Due to this long common history, there is still a Swedish-speaking minority in Finland, amounting to approximately 6 per cent of the population. Alongside Finnish, Swedish occupies the status of the other official language in the country. Therefore, all Finnishspeaking Finns must learn a certain amount of Swedish at school. There is also a Finnish-speaking minority in Sweden, the status and position of which is, however, very different from that of the Swedish-speaking Finns. The Finnish-speaking minority accumulated in Sweden predominantly in the 1950s, late 1960s and early 1970s because of a lack of jobs in Finland. Despite appeals, Swedish governments have constantly refused to acknowledge Finnish as an official minority language in Sweden. 
The Swedish Nordbanken had its origin in PKbanken (Post och Kreditbanken), founded in 1974 through a merger between Sveriges Kreditbank and Postbanken. As the name indicates, the bank was connected to the postal system of the Swedish state. In 1990, PKbanken acquired what was then called Nordbanken, which also became the name for the new merged bank. Nordbanken was the bank most badly hit by the Swedish banking crisis in the late 1980s and early 1990s, and its rescue required a great deal of capital from the Swedish state. The newly formed Nordbanken was a distinctly private customer-oriented bank.

The Finnish Merita Bank was also a product of earlier mergers and acquisitions. The latest took place in February 1995, when the two largest and most influential commercial banks in Finland, the Union Bank of Finland (UBF) and Kansallis Banking Group joined forces. The new name Merita Bank was launched some three months later. It is important to note that while UBF's image was bilingual (i.e. including Swedish-speaking Finns), Kansallis had a distinctively Finnish image. In media texts on the merger of the banks, employees of the former UBF were sometimes referred to as 'Serbs' while former Kansallis employees were referred to as 'Croats'.

In October 1997, the Nordbanken and Merita announced their decision to merge. At the time, it was the largest merger ever to take place between Sweden and Finland measured in terms of personnel and turnover. The negotiations between the parties started from broader reflections concerning the future of the banking industry, leading to specification of a business model that would form the basis for the post-merger organization. Key ideas were to build 'a regional bank of international size' and to provide a basis for further geographical expansion in the Nordic and Baltic regions. This was related to a view according to which cross-border mergers and acquisitions would inevitably transform the nature of the Nordic and European banking and finance sector and that it would be worthwhile to be among the first movers. In these negotiations, it also rather soon became apparent that this would be a 'merger of equals'; otherwise it would be very difficult to accept in Finland and Sweden. This posed specific challenges as to the division of ownership and creation of balance of power within the post-merger organization.

At the last stretch of the negotiations, there were several key issues on the table concerning, for example, positions in board and executive management. At this stage, it was decided that Hans Dalborg, a Swede and the CEO of Nordbanken since 1991, was to be 
appointed CEO of MeritaNordbanken. Vesa Vainio, a Finn (CEO of UBF in 1993-95 and Merita Bank in 1995-97), was to be appointed chairman of the board of directors. Vainio was, however, only to hold this position for the first full year following the merger. The position was then to be handed over to Jacob Palmstierna, a Swede, and Vainio was to become vice chairman. Otherwise, the positions in the executive management and board of directors were evenly split.

Among the smaller issues, the question of the language of the top management of the new bank was on the table. Ironically, it was the Finn Vesa Vainio who suggested that the new top management would use Swedish. The reasons for this were apparently pragmatic; the Swedes had Swedish as their mother tongue and all the Finnish top managers spoke (supposedly) fluent Swedish. This decision was later described as something that just 'happened by accident', as a key negotiator on the Finnish side put it:

Perhaps it just sort of happened by accident. There are good reasons - and were at the time [i.e. when the choice was made]. You really save a lot in, for example, documentation costs because documentation on one side, at least, is already in Swedish, and also part of the documentation on the Finnish side is in Swedish. If we had chosen English, we would have had all the documentation in a language foreign to both sides.

Viewed socio-historically, this was, however, a controversial decision. As is often the case with social action, this 'decision' or 'act' was later interpreted in different ways and resulted in unintended consequences (e.g. Giddens, 1984). In fact, this policy became a major issue of debate within the new organization of MeritaNordbanken and attracted considerable media coverage, especially in Finland. As a result, the corporate management had to justify the decision made, for example, by referring to pragmatic needs, to the proficiency of the Finns in Swedish and to the inadequate English skills of Nordbanken staff. Later, it was also specified that this language policy would only apply in areas where it was meaningful, that is, in top management meetings and those business operations where interaction between Finns and Swedes was liveliest. As a key Finnish manager put it:

Of course, this only concerns part of the bank; it concerns the senior management and those units where the people are in daily contact. In Utsjoki or Rovaniemi [Finnishspeaking towns in northern Finland], the language doesn't play a role. 
In many ways, the language choice created internal problems on the Finnish side ofthe organization. For example, it became apparent that the Swedish language skills of the Finns were on average much poorer than anticipated by the top management. In fact, the language issue remained an issue of debate until the next step in the development of this Nordic banking group. This took place when MeritaNordbanken made public its decision to merge with the Danish financial services group Unidanmark in March 2000. At this point, the corporate management announced that English would be the new official corporate language.

\section{LANGUAGE SKILLS AS EMPOWERING AND DISEMPOWERING RESOURCES IN SOCIAL INTERACTION}

In the context of episodic social interaction, the language skills can be seen as empowering or disempowering resources. As is often the case, it was among those who lacked the skills that the power implications of the language policy were most prevalent. We can specifically point out (1) how the language skills became empowering or disempowering resources in communication, (2) how the language skills were closely related to professional competence, and (3) how this resulted in restructuring of social networks within the bank.

Our observational data and interviews with present and former MNB employees clearly demonstrate how Finnish managers and members of staff felt handicapped by their limited communication skills. In this situation, the majority of the Finns within MeritaNordbanken started to invest in reaching a level of Swedish adequate to handle everyday communication with the Swedes. Those responsible for MNB's language policy could soon recite that 'learning Swedish quickly became very popular' - to the extent that, due to cost reasons, those not in daily contact with the Swedes could not be provided with intensive training. A comment by an interviewee in an expert position demonstrates a typical stance to the language issue among the Finnish-speaking managers, recognizing the problems but trying to take a pragmatic approach:

When it was first officially announced that the corporate language would be Swedish, the hairs on the back of my neck stood up! But on the other hand, with Finnish 'sisu' [Finnish word for 'stamina'], you decide that as you have studied the language [at school] in the past, you will start speaking it. 
It is, however, artificial to distinguish communication skills from professional competence when working as a bank manager. Being a banking professional requires ability to conceptualize organizational issues in sharp and persuasive ways, argumentation skills, and fluency in negotiations. For example, the Finnish-speaking top managers had frequently considerable difficulty in communicating their views and expertise in meetings where Swedish was used. Particular problems were manifested when producing written reports in Swedish. These problems created a strong sense of professional incompetence among many Finns. As a case in point, a secretary to senior management commented on language as power:

In the beginning it was, of course, a terrible shock . . . It was really horrible. It felt like ... half of our professional competence had been taken away when we had to use a language that was not our own native tongue. You felt like an idiot ... The main thing was to get over the feeling of inferiority.

Similarly, in a meeting between academics and representatives of the Finnish MNB organization, a Finnish senior manager spontaneously remarked how the Swedish language caused major problems for the Finns. She illustrated the type of Swedish spoken by Finns as the 'me Tarzan, you Jane' talk, and confirmed the influential role of language in building and maintaining professional competence.

Some, in turn, took the position of 'hard-boiled, speakers of bad Swedish' and decided to express their views with the language skills at hand - and thus to continue 'working as before'. These persons sometimes turned the language disadvantage into an advantage:

With Finnish as your native tongue ... you are, in a debate or negotiation situation, in a weaker position ... Whether or not this is the case, it feels like it when the other person speaks his/her native tongue ... But, turning it the other way around, we have this secret language [i.e. Finnish] in which we can speak pretty freely to each other in the middle of the negotiation. The majority of the Swedes don't understand one single bit of it.

At some stage I sort of turned it around; hey, I can at least talk to those people in Swedish, but they can't say a word of Finnish. 
The standard international practice of using English in banking business provided the Finnish-speaking Finns with an additional reason to revert to English as often as possible. It is important to note that for the Finns using English was a sign of 'equality' vis-à-vis Swedes. In this way, they had professionally the same starting point as their Swedish counterparts. A Finnish member of the corporate executive management described his approach:

In my own business area I immediately said that sorry, we are speaking English here and that I want all the reports in English.

A middle manager elaborated on his resistance strategy as follows:

There is this professional slang . . . in English. I have noticed that I get by with my 'pub Swedish' in all [situations] but when we start talking strictly business . . . English is really easier . . . I stick to English when we talk business, because I think it's more fair.

Moreover, because of English-speaking customers English became the 'natural choice' for communication in several MNB units and situations. For example, a manager in a specialist position explained that in her unit English had been 'chosen as the working language'. Consequently, while the daily oral communication between the employees was in Swedish, all written material was produced in English. When asked whether she had heard of any problems in the bank related to language and cross-national co-operation, she laughed:

Yes, a lot! Really a lot. We do have lots of people in the bank who don't master Swedish at all or only barely. It does cause problems to those people who belong to organizations where - unlike us who have English - Swedish is spoken. In meetings and the like, Finns remain silent if they are not capable [of speaking the language].

The last sentence above brings to the fore a key question concerning the role of language in the construction of professional identity. One is forced to remain silent in situations where professionalism would require active participation.

In this context, the Swedish speaking Finns, a minority group in MeritaNordbanken, are a special case. They benefited considerably from the new language policy, as in the new context they had specific resources that their Finnish-speaking colleagues lacked. It should be noted that most of the Swedish speaking Finns were actually bilingual (mastering both 
Swedish and Finnish), which gave them a unique position in internal communication within the Finnish-Swedish organization. Consequently, many Swedish-speaking Finns became natural liaisons and gatekeepers of information in Finnish-Swedish interaction and decisionmaking. This was the result of people choosing the 'natural' and 'effective' communication channels, which in practice meant often favouring those persons who were bilingual. In this way, the power position and influence of many Swedish-speaking Finns grew far greater than their official position would have implied. However, although their language skills provided them with new opportunities, ironically some of them suffered professionally. In fact, a number of Swedish-speaking Finns had eventually to be 'protected' from being overloaded by work as 'translation machines'.

\section{THE (RE)CONSTRUCTION OF IDENTITY AND SUBJECTIVITY}

When the language issue is examined from the perspective of the construction and reconstruction of particular identities and subjectivities, sense can be made of the broader significance of choosing Swedish as the official corporate language in MeritaNordbanken. In brief, this can be seen as part of a complex identity/subjectivity creation process involving concurrent (1) re-examination of the professional identity as outlined above, but also (2) reconstruction of the national identity, and (3) gradual development of a multinational corporate identity detached from the national categorization. Most interesting in the case of national identity (re)construction in this case are the specific meanings and membership categories, which have historically become associated with 'Finnishness' and 'Swedishness' in Finland.

The relationship between Swedes and Finns can, from a historical perspective, be conceptualized as post-colonial (cf. Prasad, 1997; Saïd, 1979). In the setting of Swedes and Finns in MeritaNordbanken, national identification around the language issue seems to have vitalized historically constructed conceptions of superiority (Swedes) and inferiority (Finns).

The importance of the language question was manifested in the broad media coverage in Finland. In this coverage, language emerged as part of a broader debate about the Swedes assuming - or taking over - power in MeritaNordbanken. It is illustrative that the reporting often used sports metaphors typical in the construction of national identities; 'Finland loses 6-5 in the organization game' (title in Kauppalehti, addressing the line-up in the board of 
directors, 14 October 1997), 'Nordbanken - Merita 1-0' (title in Ilta-Sanomat, the major tabloid, 5 November 1997), 'Business Units: Sweden 3, Finland 2' (sub-title in Ilta-Sanomat addressing the new organization structure of the bank, 19 December 1997), and 'The Score in the International Seems to be 0-1 for the Swedes' (a title in Helsingin Sanomat, the leading daily newspaper, 28 October 1998).

When the Swedish CEO of MeritaNordbanken, Hans Dalborg, was interviewed in Kauppalehti, the leading daily business newspaper in Finland, immediately after the merger had been announced, one of the subtitles of the article was 'Does the Spirit of an International Match Live on?' Among other themes, the journalist brought up the issue of language in the interview. In response, Dalborg linked language with integration in the new bank:

Creating a joint corporate culture is extremely important, Dalborg emphasizes. He says that creating mutual understanding is made easier by the fact that Merita is a completely bilingual bank. According to him, Swedish has always been used in the negotiations. (Kauppalehti, 15 October 1997)

This text was published before Swedish was announced as the top management language in MeritaNordbanken. Evidently, Dalborg made it sound natural that Swedes and Finns (from 'a completely bilingual bank') in general communicate in Swedish and should continue to do so in the future. Interpreting his line of thought, the 'joint corporate culture' or 'mutual understanding' was to be built using the Swedish language. As indicated earlier in this paper, however, Merita was far from a 'completely bilingual bank'.

From a Finnish perspective, then, CEO Hans Dalborg's comment above on Merita as a 'completely bilingual bank' aptly exemplifies the common ignorance among Swedes about contemporary Finnish society and the role of the Swedish language in Finland. Such comments can be interpreted to have taken part in triggering unintentional consequences; the fragile 'Finnish identity' vis-à-vis the Swedish was threatened and provoked. In general, it seems that a large number of employees on the Finnish side of MeritaNordbanken interpreted the language policy as a sign of Swedish dominance. Such a choice of corporate language was considered a clear message from top management regarding the division of power. 
Some two weeks after Hans Dalborg's interview quoted above, in an interview with Ilta-Sanomat (the leading Finnish tabloid), Vesa Vainio, the Finnish chairman of the board, defended this choice as follows:

When the Finnish Merita and the Swedish Nordbanken merge, the official language of the new bank will be Swedish, the chairman of the board in the new big bank, Vesa Vainio assured yesterday. According to Vainio, the decisive issue is that the Swedes' skills in Finnish are considerably weaker than those of the Finns in Swedish. Top managers in Merita have been wishfully thinking that English, the only international banking language, would become the final official language in the bank. Such dreams will now not come true.

The choice of words (by the journalist) is noteworthy. English and Finnish (the 'unsaid' element in the text) are constructed as unattainable 'dreams' in MeritaNordbanken. This metaphor is used again as the text continues:

Vainio said that in daily routines in both countries the local language can be used. However, climbing up the corporate ladder to top positions in the bank is not possible without fluency in Swedish. Skills in the Finnish language have, however, not been set as a requirement for reaching the board level.

For a Finnish reader, it is difficult to ignore the irony in the commentary. It is wellknown that extremely few Swedes have made an effort to learn Finnish, and even fewer have learned it.

An 'inferiority' discourse surfaced especially in situations where the Finns felt they had suffered from injustice or had been placed in disadvantageous positions vis-à-vis their Swedish counterparts. A Finnish middle manager in MeritaNordbanken describes friction with the 'Swedes' with an interesting post-colonial association of Swedes and 'white men':

Finns perhaps have this feeling of inferiority. We do a hell of a job and make progress ... We are tough, but if someone comes and asks 'What are you doing?', we say 'Well, I don't really know'. Swedes do it the other way around. Even if they know nothing about the issue, they hold their heads up high and sell it. That coheres with this 'white man' attitude. 
The cultural seminars in MeritaNordbanken also pointed to a relationship of superiority and inferiority between the Swedes and the Finns. Clearly, it could be observed that the Swedes regarded the choice of language as self-evident and/or a relief. In contrast, for the Finns, the corporate language appeared as something imposed on them by a superior counterpart. It is interesting to note that this view shared by most Finns seems to have been a genuine surprise to many Swedish managers. For example, in a consulting report carried out by the Swedes soon after the merger, negative responses by the Finns on the language policy issue had not been at all noted.

Following the negative reactions on the Finnish side, the corporate management, however, became increasingly concerned about such reactions. A Swedish top manager described the actions taken to 'remedy' the situation:

The starting point was that we speak Swedish within the top management and board, and we followed that all the time. But this was misinterpreted in a very different way down in the organization: 'Do we now have to speak good Swedish to have career options?'. So gradually, it took a couple of months, we went out and said that of course we use the language that we are most comfortable with. In the Swedish branch offices we speak Swedish, in Jyväskylä and Rovaniemi [Finnish towns] we speak Finnish and possibly even in the most Eastern branches Russian.

A couple of Swedish top managers also started to learn some Finnish. One of them described his experiences as follows:

Finnish is a very difficult language, and the value of trying to learn some Finnish was not to be able to speak any real Finnish but to know whether it says 'or 'gentlemen' on the door, where I should go in. It was not much but enough to get an increased understanding of the communication problems and the challenges of our Finnish colleagues [learning Swedish].

As pointed out by both Finns and Swedes, these efforts to learn Finnish had symbolic importance and were highly appreciated by the Finns. It was therefore that the Swedish CEO Hans Dalborg made public his efforts to learn Finnish. From early on, he made a habit of including short Finnish passages in his formal speeches in Finland. 
The particular position of the Swedish-speaking Finns in MeritaNordbanken deserves again further attention. On the one hand, the Swedish-speaking Finns were often associated with the legacy of UBF, the Swedish-speaking part of the original Merita Bank. This meant that Swedish-speakers as a perceived collective were viewed as 'winners' by the Finnishspeaking Finns identifying with the former Kansallis. For example, a Finnish middle manager brought to the fore the symbolism associated with the power of language. 'Them' refers both to Swedes and Swedish-speaking Finns:

The fact that the corporate language is Swedish really did . . . intuitively give them a power position ... right from the beginning. Perhaps for the top management it wasn't a problem, because practically speaking, all Merita top managers were from the UBF side and they spoke, of course, a lot of Swedish in UBF.

On the other hand, however, it is evident that the Swedish-speaking Finns themselves were at times regarded as inferior compared with the 'real' Swedes in MeritaNordbanken. The 'real' Swedes frequently viewed the dialect of the Swedish speaking Finns as awkward and old-fashioned. The pronunciation, for example, is markedly different. So are some of the words and terms used; in a number of instances, texts already checked by a Swedish-speaking Finn in Merita had to be 'recorrected' by a Swedish colleague to match 'rikssvenska', the 'real' Swedish spoken by 'real' Swedes. Such a procedure was humiliating for a number of Swedish-speaking Finns. As a result of internal discussions, there were for a period of time three versions of the staff newsletter: Swedish (riksvenska), Swedish (in Finland) and Finnish.

\section{THE REIFICATION OF STRUCTURES OF DOMINATION}

The case clearly illustrates significant longer-term implications of the language policy issue. As the specific identities/subjectivities and the related practices described above became institutionalized and normalized, we can speak of the reification of structures of domination, or naturalized hierarchical relationships within the new post-merger organization. We can specifically point to two emerging structures of domination: (1) the post-colonial structure emerging as a result of both imposed control but also by the voluntary strategization of the (supposedly) dominated Finnish-speakers, and (2) the neo-colonial structure exemplified by the legitimization and normalization of language policies per se. 
As to the post-colonial structure, the career discourse and strategies of the Finnishspeaking Finns are probably the clearest examples of the enacted structural implications of the language policy decision. In brief, many of the Finns had to invest heavily in learning Swedish and ultimately accept an in-built inequality when pursuing their banking careers. Others reverted to those kinds of places and positions within the organization where their 'insufficient' language skills would not cause problems. In fact, many employees sought to 'escape' the Swedish language through internal mobility. Such 'Finnish-speaking havens' could be found, for example, within the domestic Finnish branch network where direct contacts with Swedish colleagues were rare. Finally, many people apparently also decided to leave the bank. As a top Finnish banker in MeritaNordbanken put it:

In Finland, we lost many potential future key figures because they realized that they would never be able to compete with their Swedish rivals in the organization.

The point is that through such strategies and moves the Finnish-speakers were themselves actively constructing the 'reality' of 'career segregation'.

Interestingly, the decision to later change the official corporate language to English was interpreted precisely as a demolishing of a structure of domination in Finland. The Finns typically pointed to 'a relief' and 're-established equality'. According to our interviews and observations, many Finns continued to use Swedish with their Swedish colleagues in informal encounters. However, especially in the more official meetings and decision-making forums, a great number of Finns were eager to 'exercise their new rights' by switching to English and consequently 'showing the Swedes their place'.

While most of the Finns indeed saw the new language policy based on English as a 'relief', the Swedes saw problems with this choice. Ironically, just like the Finns in the case of choosing Swedish, our Swedish interviewees could point to new emerging difficulties for those not mastering English:

I am a little bit afraid that we are losing some competent people who will come become silent, who are not as good (as others) in this language . . . A lot of culture creation, cooperation and consensus, it is precisely participation in these joint meetings. And if one then only sits there and does not understand every nuance or value ... 
The case also illustrates how the discourse around the language policy itself led to the legitimization and naturalization of this neo-colonial control mechanism. This can be seen as an example of an innovation in techniques of discipline in the sense of Clegg (1989) or Foucault (1984). In fact, the language choice caused a lively discussion among the workforce, stakeholders and general public in Finland - but also in Sweden. Even after some time had elapsed, some key decision makers stuck to the rationale of the initial decision and justified the decisions, for example, in the interviews we carried out, as in the following comment by a Finnish top manager:

Yes, it is important to note that it [Swedish] was intended as the language for the management and the board of directors. When this caused discussion I said that just go ahead and speak any language that all the people around the table understand. It doesn't matter as long as people understand each other and we speak the language of the customer, if we just can.

However, most Finnish people, including most members of the top executive management, saw the initial decision as a mistake, as the following reflections of two key persons illustrate:

One can see this language issue as a strategic mistake, which was made a bit carelessly at some point in the merger negotiations.

I'd say it [the choice of Swedish] was a mistake. This might be a bit difficult for the Swedes to admit. For us [Finns], it is perhaps a little easier.

The Swedish top managers were, in turn, more divided in terms of their comments in our retrospective interviews. In justifying the initial decision, many of them referred to the fact that the Finns themselves suggested this policy. While acknowledging the difficulties, they, however, most often seemed to subscribe to the rationale of the initial decision, as in the following:

I think that the language issue was rather quickly solved. Here we agreed from day one ... And then many Finns learned Swedish and things like that. It was also a little bit fashionable [for the Swedes] to study some Finnish and learn to express oneself [in Finnish]. I thought that it was corny, to put it bluntly, because it did not really help anything. The Finns have a different situation as they have studied Swedish four years 
as an obligatory first foreign language [misunderstanding; it is usually the second foreign language studied either for three or six years] at school, and that gives them the base to speak Swedish.

The point in this case is, however, not whether the initial decision was right or wrong but that it triggered a discussion as a result of which the need for corporate-level language policies was not questioned but promoted. The Finns, who hadin many ways felt handicapped, were eager to promote active language policies that would be based on 'neutrality', 'equality' and 'fairness', which in this case meant choosing English as the common official language and specifying degrees of freedom as to when to use local languages. In general, many Swedes also saw it as important to specify clear language policies when faced with the unintended consequences of the initial decision. However, in contrast to the Finns, many of them were ready to let the actual situations define the language used while the Finns were more categorical, obviously trying to protect the 'balance of power' in internal communication and decision-making. For example, a Finnish top manager pointed to the language use of Hans Dalborg (Swedish, old chairman) and Thorleif Krarup (Danish, new chairman of the board) as follows:

Dalborg was somewhat worse ... in that he often wanted to speak Swedish, even in official meetings. Krarup is very careful in that all the meetings are held in English, and that's it.

While understandable from the corporate perspective, this kind of language policy introduction and definition does, however, not lack further ramifications for people's ability to express themselves freely and maintain their cultural heritage. In brief, these kinds of policies promote the control and disciplinary power of a multinational corporation in ways that are ironically too obvious to be noticed. They do restrict the ability of specific people to use their mother tongue and thus draw from and maintain their cultural heritage while working in a multinational corporation. Moreover, effects are not limited only to this 'sphere' of their lives. In the contemporary world, the boundaries between working life and private life, for example in the case of banking managers, are not easily drawn. There is also the question of learning. To be able to keep up with the demands, one has to practice and study the language, which will obviously affect the social and private activities of the people involved and so forth. It is also the case that such policies create a concrete need for those 
who aspire to work as a banking professional to invest in that language and thus start complying even before they have been recruited.

The end result of this case - the choice of English as the official language - is an issue that warrants specific attention. Precisely because of the needs to communicate 'effectively', to create a 'balance of power' and to create 'neutral' language policies, English emerged as the natural choice. English thus became constructed as the 'lingua franca' or the 'universal' language that would be the most natural and legitimate choice for (at least official) communication in the multinational corporate context. This can be seen as an example of normalization (e.g. Foucault, 1984), which is particularly interesting considering the pioneering nature of this cross-national banking group in Europe. In the future, especially in the Nordic contexts, one can thus expect other cross-national banking and finance groups being built to face great pressure to adopt English as the official language when having this case in the background.

It would, however, be a mistake to think that the choice of English would be unproblematic or neutral in terms of its power implications. In this case, for example, virtually no one in the top ranks was a native speaker of English. Hence, they were forced to use an 'alien' language in their daily work. The implications related to Anglo-American cultural dominance, reinforced by the use of English, are also likely to be significant in organizations such as this, but their explicit analysis is beyond the scope of this study.

\section{CONCLUSION}

In this paper, we have examined the complex language/culture/knowledge/power interrelationships in a situation where language policies are defined in an emerging multinational corporation. Our analysis illustrates how the choice of an official corporate language is not a 'neutral' issue but has many types of power implications, which are summarized in Figure 1.

Above all this analysis points to the complexity of the power implications, which we have demonstrated by using the circuits of power framework of Clegg (1989) and by simplifying and refining his ideas for the purposes of our specific setting. Within our framework, illustrated in Figure 1, the complexity of the power relations can be understood by examining the implications at three levels of analysis. First, we can observe episodic social interaction. At this level, we can see how language skills can become empowering and 
disempowering resources in communication. In MeritaNordbanken, it was the Finnishspeaking Finns who suffered from not mastering Swedish in internal interaction. We can also look at how language is connected to interpretations and (re)constructions of professional competence. In our case, the Swedish-speaking (inadvertedly) became (constructed as) professionally more competent. We can furthermore observe how networks of communication and interaction are established based on language skills. Fluency in Swedish became the basis for such channels in our case.

Second, we can move beyond episodic social interaction and focus on deeperlevel identity and subjectivity construction processes. In multinational settings, this involves not only professional but also national and inter-national identities and subjectivities. Our analysis in particular shows how the discussions around the language issue within the organization and in the media increased national identification, confrontation and segregation while promoting the nationalist ideology. Important in these complex identification and social integration processes was the construction of images of superiority and inferiority. In this particular Swedish-Finnish setting, this construction of superiority-inferiority categories was linked with the historical colonial relationship between the two nations, and the discussions around the language issue inevitably also (re)produced post-colonial identities and subjectivities.

Third, we can finally move to examine the longer-term structural implications of the language policy decisions and analyse the consequent reification of structures of domination within and in the context of multinational corporations. This can involve many kinds of structures of domination, but post-colonial and neo-colonial ones are among the most important when dealing with contemporary language choices. In MeritaNordbanken, one can in particular point to things such as career segregation as a manifestation of the re-emerging post-colonial structure. However, interestingly, as our case shows, discussions around the language policy decisions can ultimately also legitimate and naturalize neo-colonial corporatecontrol. 


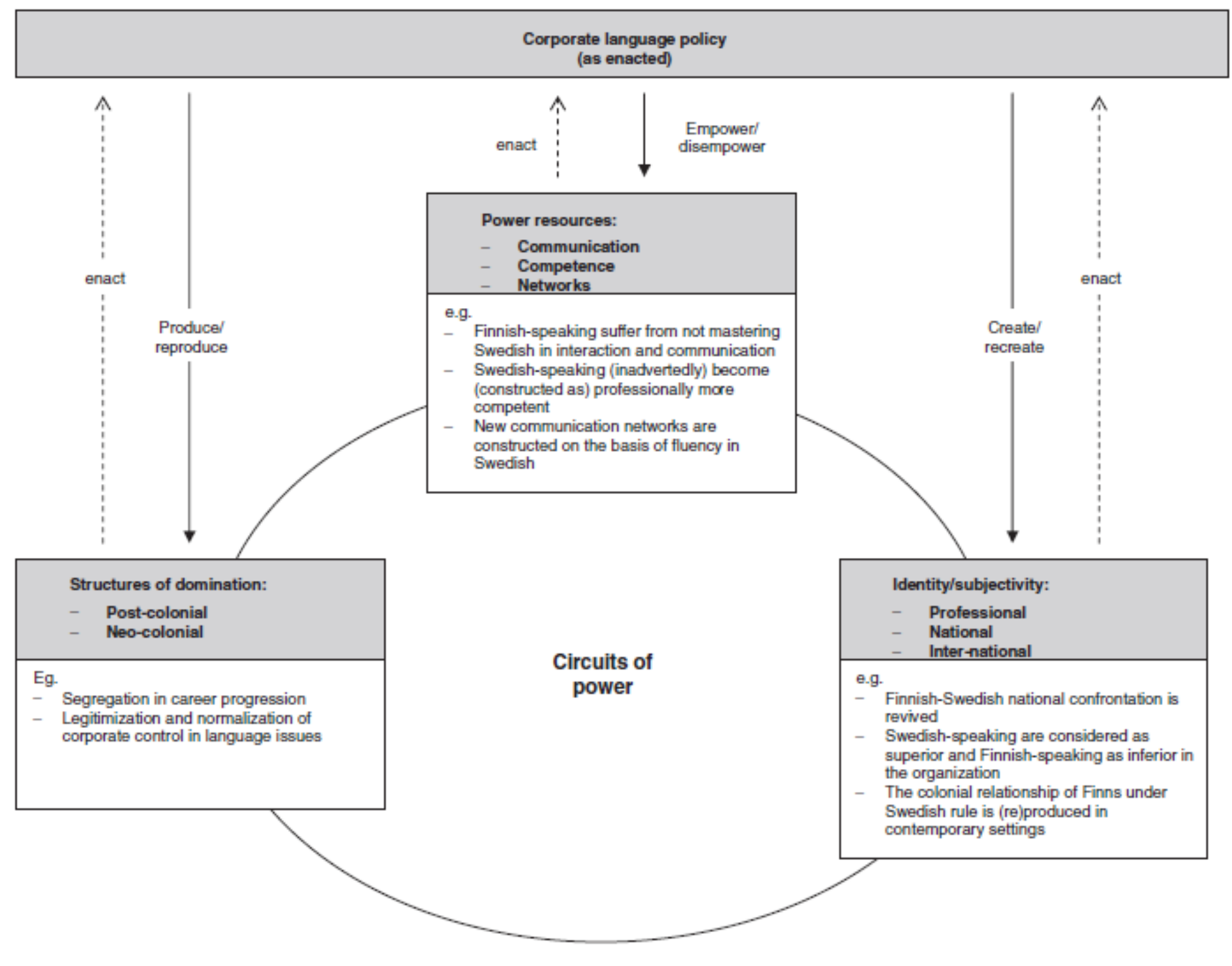

Figure 1. Power implications of language policy decisions 
This analysis also points to the ambiguity of the power implications, often emphasized in post-modern literature on power (e.g. Foucault, 1980). To pick one example, this is especially clear in the case of the Swedish-speaking Finns. In many ways, their power position was promoted by choosing Swedish as the official corporate language. Those who were bilingual found themselves in a particularly interesting position in the nexus of communication. However, not all of the consequences were only positive from their perspective. For example, they were often overloaded with communication and translation activities. In Finland they were often associated with the Swedish dominance, regarded as 'privileged' and even blamed for the problems caused. This was the case, although in Sweden they could still be seen as Little Brothers, as the example of the Swedish translations made in Finland but turned down in Sweden showed.

This analysis also highlights the central role of the interpretations and actions of the 'powerless' in enacting the power relationships. In fact, one can see the 'resistance' and 'coping' strategies of the Finnish-speaking Finns as essential elements in the circuits of power leading to their subordination and domination. This is not to cast blame on the 'victims' (e.g. those who tried to made use of Finnish as a 'secret language', reverted to English in internal communication, sought new positions with less need to speak Swedish, or decided to leave the bank), but to point out how the social dynamics in the case of such touchy issues as 'language policies' often become self-reinforcing. Similarly, one can sympathize with the difficult position created for the Swedish members of the top management of MNB who must have often felt like prisoners of the colonizer role ascribed to them by the Finns.

In this paper we have pointed to the complex and ambiguous power implications of language policies in multinational corporations. We believe, however, that the role of natural languages as symbols and signifiers of cultural heritage and dominance is overall a topic that organization scholars should take seriously and examine from different perspectives. One way to proceed is to look at different cultural, national and organizational contexts and examine specific emerging power relations. One could assume that given the particular historical relationships between particular nations, the power implications would in a finegrained analysis also be context-specific. Just to give few examples of 'problematic' relationships manifested in recent industrial restructurings, British-French, French- German, and US-German relationships all involve specific historical legacies that make them in many ways unique. Nevertheless, in many parts of the world, colonial histories and legacies are 
(re)created by the use of the colonizer's language in different spheres of society (e.g. Prasad, 1997; Westwood, 2001). In these contexts, one could expect to see similar processes as in our Swedish-Finnish case.

The case also showed how, after the troublesome experiences, English became constructed as the legitimate official corporate language, which can be seen as an example of a normalization of Anglo-American cultural dominance in multinationals. In fact, it is instances such as this one, which show how 'globalization' often means voluntary acceptance of such imperialism. What is most interesting in this context is that English was sneaked in by the 'voluntary' decisions of the dominated themselves. It seems apparent that mapping out such decision-processes and their cultural implications in different contexts would greatly enhance our knowledge of the micro-level globalization processes in multinational corporations.

In addition to the ideas presented in this paper emphasizing the problematic and negative power implications of language policies, future studies could also look at the 'positive' or 'facilitative' aspects of identity and subjectivity construction related to language and communication policies. One could, for example, examine what kind of subjectivity and identity construction the adoption of English as the official corporate language can actually mean in different circumstances. In this context, one could also examine in more detail the various 'technologies of the self' (Foucault, 1988) that the people can use when trying to better control their own lives.

It should also be noted that this study provides a clear illustration of the inherently political nature of multinational corporations. This should not come as a surprise for most sociologically or linguistically oriented organization or management scholars, but is something that has to large extent been missing in research on multinational corporations. In fact, there is an apparent need to focus more attention on the inherent tensions created by corporate control and various cultural and nationalistic forces in future research on multinational corporations. As shown in our analysis, these forces can be visible in daily social interaction but understanding their broader significance requires an analysis of identity and subjectivity construction and reflection on the broader institutional ramifications. In addition to language policies, mapping out and analysing the political processes of multinational corporations should involve looking at issues such as the location of headquarters, division of top positions, ownership structures, division of roles and 
responsibilities among the different locations and workforce, differences in compensation etc. At a more theoretical level, there also seems to be a need to develop our conceptions of multinational corporations to make the culture-powerdominance link visible. As this study has shown, Clegg's integrative framework can, with due caution and specification, be used as a solid theoretical basis for such reflection.

In conclusion, corporate language policies are easily seen as 'practical', 'inevitable' and even 'natural'. Whether we like it or not, they also involve power implications that are easily overlooked. As important cultural subjugation processes in multinational corporations, they should, however, be taken seriously.

\section{NOTES}

[1] According to Lukes (1974), the powerless are not either able to recognize - not to speak of expressing - their 'real' interests. The idea of 'real interests' has thereafter been strongly questioned, for example, by 'post-structuralists' (e.g. Foucault).

[2] We want to gratefully acknowledge the contribution of Ingmar Björkman, Karl-Olof Hammarkvist, Tore Hundsnes, Christine B. Meyer, Annette Risberg, and Anne-Marie Søderberg to this research project. 


\section{REFERENCES}

Alvesson, M. and Willmott, H. (1996). Making Sense of Management: A Critical Introduction. London: Sage.

Anderson, B. (1983). Imagined Communities: Reflections on the Origin and Spread of Nationalism. London: Verso Editions and NLB.

Bachrach, P. and Baratz, M. Z. (1963). 'Decisions and nondecisions: an analytical framework'. American Political Science Review, 57, 641-51.

Ball, K. and Wilson, D. (2000). 'Power, control and computer-based performance monitoring: repertoires, resistance and subjectivities'. Organization Studies, 21, 539-65.

Banerjee, S. B. and Linstead, S. (2001). 'Globalization, multiculturalism and other fictions: colonialism for the new millennium?'. Organization, 8, 683-722.

Berger, P. L. and Luckmann, T. (1966). The Social Construction of Reality. New York: Doubleday.

Brocklehurst, M. (2001). 'Power, identity and new technology homework: implications for "new forms" of organizing'. Organization Studies, 22, 445-66.

Carter, P. and Jackson, N. (2004). 'For the sake of argument: towards an understanding of rhetoric as process'. Journal of Management Studies, 41, 469-91.

Child, J. and Tsai, T. (2005). 'The dynamic between firms' environmental strategies and institutional constraints in emerging economies: evidence from China and Taiwan'. Journal of Management Studies, 42, 1, 95-125.

Clegg, S. R. (1975). Power, Rule and Domination: A Critical and Empirical Understanding of Power in Sociological Theory and Organizational Life. London: Routledge and Kegan Paul.

Clegg, S. R. (1987). 'Discussion note: the language of power and the power of language'. Organization Studies, 8, 61-70.

Clegg, S. R. (1989). Frameworks of Power. London: Sage. 
Deetz, S. (1992a). Democracy in the Age of Corporate Colonization: Developments in Communication and the Politics of Everyday Life. Albany, NY: State University of New York Press.

Deetz, S. (1992b). 'Disciplinary power in the modern corporation'. In Alvesson, M. and Willmott, H. (Eds), Critical Management Studies. London: Sage.

Ezzamel, M.,Willmott, H. and Worthington, F. (2001). 'Power, control and resistance in "The factory that time forgot"' '. Journal of Management Studies, 38, 1053-79.

Fairclough, N. (1997). Critical Discourse Analysis: The Critical Study of Language. London: Longman.

Foucault, M. (1977). Discipline and Punish: The Birth of the Prison. Harmondsworth: Penguin.

Foucault, M. (1980). In Gordon, C. (Ed.), Power/Knowledge: Selected Interviews and Other Writings 1972-1974. Brighton: Harvester Press.

Foucault, M. (1984). The History of Sexuality: An Introduction. Harmondsworth: Penguin.

Foucault, M. (1988). 'Technologies of the self'. In Martin, L., Gutman, H. and Hutton, P. (Eds), Technologies of the Self. Amherst, MA: University of Massachusetts Press.

Garfinkel, H. (1967). Studies in Ethnomethodology. Englewood Cliffs, NJ: Prentice-Hall.

Giddens, A. (1984). The Constitution of Society. Cambridge: Polity Press.

Gowler, D. and Legge, K. (1981). 'Negation abomination and synthesis in rhetoric'. In Antaki, C. (Ed.), The Psychology of Ordinary Explanations of Human Behaviour. London: Academic Press.

Gramsci, A. (1971). Selections from the Prison Notebooks. London: Lawrence and Wishart.

Grant, D., Keenoy, T. and Oswick, C. (Eds) (1998). Discourse and Organization. London: Sage.

Hamilton, P. M. (2003). 'The saliency of Synedoche; The part and whole of employment relations'. Journal of Management Studies, 40, 7, 1569-85. 
Harley, B. and Hardy, C. (2004). 'Firing blanks? An analysis of discursive struggle in HRM'. Journal of Management Studies, 41, 3, 377-400.

Kennedy, V. (2000). Edward Sä̈: A Critical Introduction. Oxford: Polity Press.

Knights, D. and McCabe, D. (1999). “"Are there no limits to authority?": TQM and organizational power'. Organization Studies, 20, 197-224.

Knights, D. and Willmott, H. (1989). 'Power and subjectivity at work: from degradation to subjugation in social relations'. Sociology, 23, 535-58.

Korten, D. (1996). When Corporations Rule The World. West Hartford, CA: Kumarian Press.

Laclau, E. and Mouffe, C. (1985). Hegemony and Socialist Strategy. London: Verso.

Lukes, S. (1974). Power: A Radical View. London: Macmillan.

Marschan-Piekkari, R., Welch, D. and Welch, L. (1999). 'In the shadow: the impact of language on structure, power and communication in the multinational'. International Business Review, 8, 421-40.

McKinlay, A. and Starkey, K. (Eds) (1998). Foucault, Management and Organization Theory. London: Sage.

Miller, S. J., Hickson, D. J. and Wilson, D. C. (1996). 'Decision-making in organizations'. In Clegg, S. R., Hardy, C. and Nord, W. R. (Eds), Handbook of Organization Studies. London: Sage.

Mintzberg, H. (1983). Power In and Around Organizations. Englewood Cliffs, NJ: Prentice Hall.

Pettigrew, A. M. (1973). The Politics of Organizational Decision-making. London: Tavistock.

Pfeffer, J. (1992). Power in Organizations. Boston, MA: Pitman.

Prasad, A. (1997). The Colonizing Consciousness and Representations of the Other. In Prasad, P., Mills, A. J.,

Elmes, M. and Prasad, A. (Eds), Managing the Organizational Melting Pot. London: Sage. 
Prasad, A. (Ed.) (2003). Postcolonial Theory and Organizational Analysis: A Critical Engagement. New York: Palgrave MacMillan.

Saïd, E. W. (1979). Orientalism. New York: Vintage.

Silverman, D. and Jones, J. (1974). Organizational Work: The Language of Grading and the Grading of Language. London: Collier Macmillan.

Thompson, J. D. (1956). 'Authority and power in identical organizations'. American Journal of Sociology, 62, 290-301.

Townley, B. (1993). 'Foucault, power/knowledge and its relevance for human resource management' Academy of Management Review, 18, 518-45.

Vaara, E. and Tienari, J. (2002). 'Justification, legitimization and naturalization of mergers and acquisitions: a critical discourse analysis of media texts'. Organization, 9, 275-303.

Van Maanen, J. (1988). Tales of the Field: On Writing Ethnography. Chigago, IL: The University of Chigago Press.

Westwood, R. (2001). 'Appropriating the other in the discourse of comparative management'. In Westwood, R. and Linstead, S. (Eds), The Language of Organization. London: Sage.

Westwood, R. and Linstead, S. (Eds) (2001). The Language of Organization. London: Sage.

Wittgenstein, L. (1968). Philosophical Investigations. Tr. Anscombe, G. E. M. Oxford: Blackwell. 